Acta vet. scand. $1970,11,427-442$.

From the Department of Obstetrics and Gynaecology, Royal Veterinary College, Stockholm, Sweden.

\title{
DEVELOPMENTAL ABNORMALITIES OF FEMALE SEXUAL ORGANS IN SWINE
}

A POST-MORTEM EXAMINATION OF THE GENITAL TRACT IN 1,000 GILTS

by

Stig Einarsson and Börje Gustafsson

Developmental abnormalities of the female sexual organs in Swedish cattle breeds and the importance of such abnormalities in causing reproductive disturbances have been the subject of comprehensive investigations in Sweden (Eriksson 1943; Lagerlöf \& Boyd 1953; Lagerlöf et al. 1958; Settergren \& Galloway 1965). Similar investigations have not been made in swine. The reasons for this may be the limited possibility of clinical diagnosis of abnormalities in the internal sexual organs of swine. Although the pig is a relatively fertile animal (Teige 1957), abnormalities of the sexual organs in swine will cause impaired fertility or sterility as evident from studies made in other countries (Wiggins et al. 1950; Goethals 1951; Perry \& Pommery 1956; Teige; Nalbandov 1964) and reviewed, e.g. by Roberts (1956). Developmental abnormalities of sexual organs in swine have been described (Holst 1949; Johanson \& Rendel 1963), but no comprehensive investigation on the congenital malformations in female genital organs has previously been carried out in Sweden.

The present investigation was mainly conducted in order to fill this gap.

\section{MATERIAL AND METHODS}

Between March and August 1968 1,000 organs from female swine were collected at a slaughterhouse in the central part of Sweden. All organs were from nonparous swine with a body 
T a b l e 1. Malformations in 1,000 reproductive organs of gilts and their presumed significance as cause of sterility.

\begin{tabular}{lccc}
\hline Diagnosis & $\begin{array}{l}\text { Number } \\
\text { of cases }\end{array}$ & Frequency & Probable effect on fertility \\
\cline { 3 - 3 } & & sterility & $\begin{array}{l}\text { lowered } \\
\text { fertility }\end{array}$ \\
\hline
\end{tabular}

True hermaphroditism

Cysts in mesosalpinx

a) localized to infundibulum diameter $\angle 10 \mathrm{~mm}$

b) other localization

$\begin{array}{ll}3 & 0.3\end{array}$

3

Cysts in oviduct wall

(with pressure on lumen)

$\begin{array}{llll}71 & 7.1 & - & - \\ 15 & 1.5 & - & 15 \\ 54 & 5.4 & - & -\end{array}$

Local diverticulari-

zation in oviduct

Uterus unicornis

$\begin{array}{rrrr}3 & 0.3 & - & 3 \\ 14 & 1.4 & - & 14 \\ 4 & 0.4 & - & 4 \\ 1 & 0.1 & - & 1\end{array}$

Uterus didelphys and

double vagina

Segmental aplasia of uterine horn:

a) unilateral

b) bilateral

Partial double horn

$\begin{array}{ll}3 & 0.3\end{array}$

$1 \quad 0.1$

$\begin{array}{ll}3 & 0.3\end{array}$

Total duplication of:

a) vagina and cervix

b) vagina

1

1

0.1

0.1

Partial duplication of :

a) vagina and cervix

b) cervix

$\begin{array}{ll}3 & 0.3 \\ 2 & 0.2\end{array}$

c) vagina $(>1 \mathrm{~cm}$ dorsoventral septum)

41

0.3

4.1

Vagina blind at border of vestibulum vaginae

Total

1

0.1

1

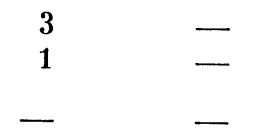

221

$221 \quad 22.1 \% \quad 8(0.8 \%) \quad 37(3.7 \%)$

weight of $85-110 \mathrm{~kg}$. The material comprises gilts which had not yet had any ovulation, hereafter called prepuberal gilts, and gilts which had had 1 or more ovulations, here called sexually 


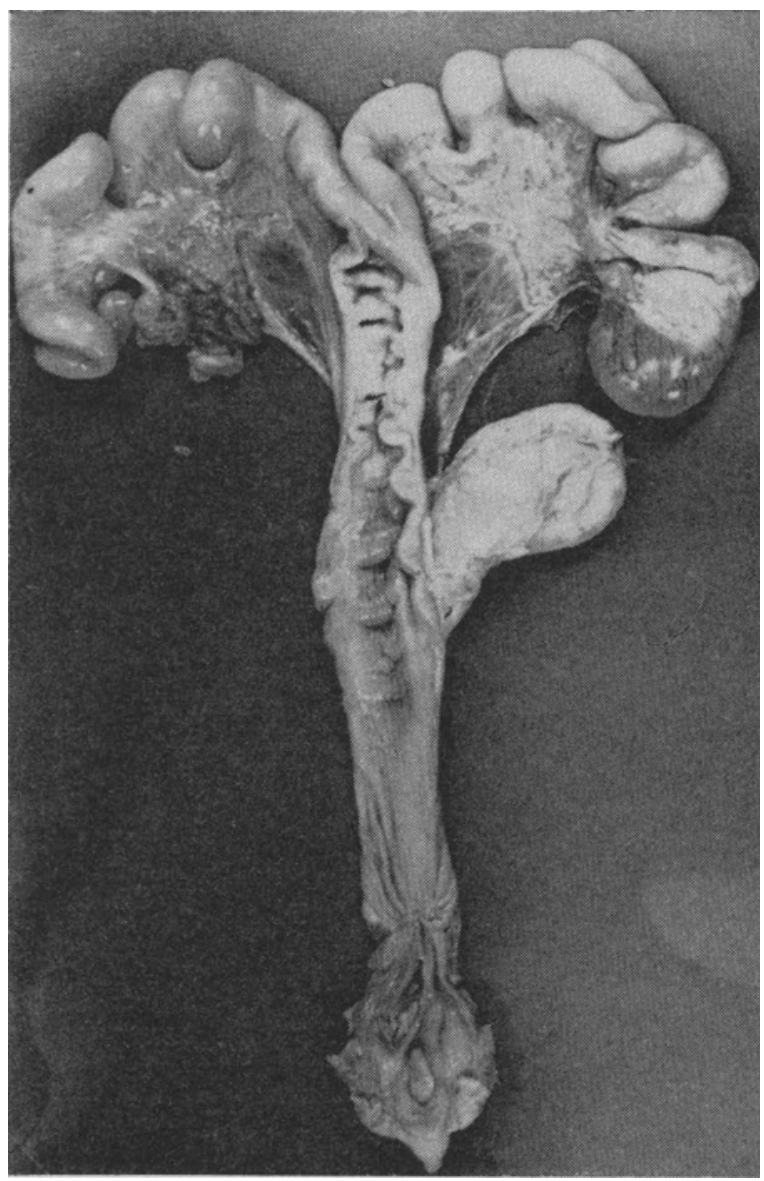

F i g u e 1. Hermaphroditism. Description see the text.

mature gilts. The organs were inspected and examined and abnormalities of the ovaries, bursae and oviducts, the uterus, cervix, vagina and vestibulum vaginae were recorded. The tubular reproductive organs were also cut open and examined for developmental abnormalities and other defects of the Müllerian duct and sinus urogenitalis. The ovaries were separated along the attachment of the mesovarium and weighed. Occurrence and number of corpora lutea (C.L.) were recorded. The corpora lutea were cut and examined for cavities (cystic C.L.). The occurrence of follicles of diameter more than $5 \mathrm{~mm}$ in ovaries was also recorded. 


\section{RESULTS}

\section{Developmental abnormalities}

The number and frequency of observed malformations in the present material are summarized in Tables 1 and 2.

H e r m a p h r oditis m

As is evident from Table 1, 3 of 1,000 examined gilts' organs were from hermaphrodites. Fig. 1 shows 1 of the hermaphrodites. The left gonad was an abnormally developed ovary (weight $2.0 \mathrm{~g}$ ) and contained several large follicles of up to $7 \mathrm{~mm}$ size. The right gonad was made up of a testis (weight $47.0 \mathrm{~g}$ ), the appearance of which resembled a cryptorchid testis, an epididymis (weight $20.0 \mathrm{~g}$ ), and a vessel plexus. The uterus was normally developed and partly filled with a yellowish transparent fluid. The vagina and the vestibulum vaginae were short and narrow, while the clitoris was greatly enlarged. Of the other 2 hermaphrodites 1 had bilateral ovotestis and the other unilateral ovotestis (right) with a normal left ovary. The ovotestis was made up of an ovary with normal follicles and corpora lutea and of a testis, the size of a pigeon egg well separated from the ovary tissue. The consistency of the testis was firm and the cut surface was somewhat dry and of a brown-yellow colour. Histological investigation revealed total absence of spermatozoa in the seminif erous tubules, which contained Sertoli cells and a well developed interstitial tissue with a number of cells similar to interstitial cells. The tubular parts of the reproductive organs were female and well

T a b l e 2. Congenital defects in oviduct and infundibulum.

\begin{tabular}{lccccc}
\hline & $\begin{array}{c}\text { Local } \\
\text { diverti- } \\
\text { cularization } \\
\text { in oviduct } \\
(3-10 \mathrm{~mm} \\
\text { diameter })\end{array}$ & $\begin{array}{c}\text { Cysts in } \\
\text { oviduct wall } \\
\text { with pressure } \\
\text { on lumen } \\
(2-6 \mathrm{~mm} \\
\text { diameter })\end{array}$ & $\begin{array}{c}\text { Cysts in } \\
\text { mesosalpinx } \\
\text { localized to } \\
\text { infundibulum, } \\
\text { diameter } \\
\leq 10 \mathrm{~mm}>10 \mathrm{~mm}\end{array}$ & $\begin{array}{c}\text { Other } \\
\text { locali- } \\
\text { zation }\end{array}$ \\
\hline $\begin{array}{l}\text { Unilaterally } \\
\text { number }\end{array}$ & 11 & 3 & 61 & 11 & 51 \\
$\begin{array}{l}\text { Bilaterally } \\
\text { number }\end{array}$ & 3 & - & 10 & 4 & 3 \\
Total & 14 & 3 & 71 & 15 & 54 \\
Frequency & $1.4 \%$ & $0.3 \%$ & $7.1 \%$ & $1.5 \%$ & $5.4 \%$ \\
\hline
\end{tabular}




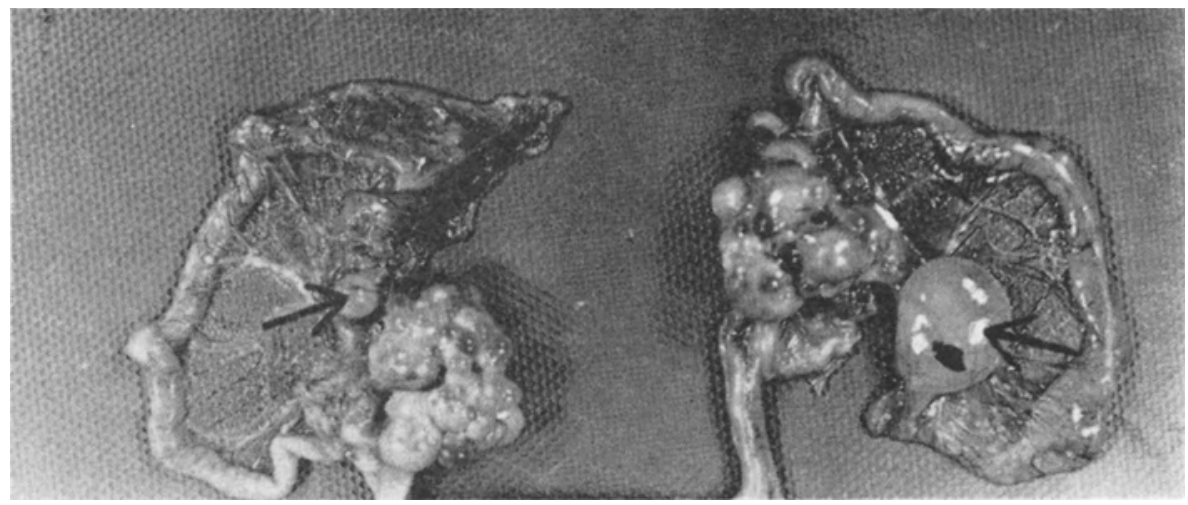

Figure 2. Cysts in mesosalpinx, localized to infundibulum and its fimbria (bilaterally).

developed except for the oviducts. Instead of real oviducts there was an approx. $10 \mathrm{~cm}$ long string of $2-3 \mathrm{~mm}$ thickness, with origin in the wall of the apex of the uterine horn. The string was canalized but ended blind just at an epidymal-like structure of $10 \mathrm{~cm}$ length near the gonads. Histological examination of the strings revealed a structure similar to the endometrium. Thus the tubular string was probably a continuation of the uterine horn.

Local developmental abnormalities

Aplasia or hypoplasia of the ovaries was not found. In 1 case, however, the difference of weight between the ovaries was so large that a hypoplasia was suspected. The weight of the right ovary was $1.0 \mathrm{~g}$ and of the left $5.0 \mathrm{~g}$. In the left there were 8 follicles, $8-10 \mathrm{~mm}$ in size, but no corpora lutea. The right ovary was formed like a kidney with a smooth surface. The external surface of the cortex revealed an approximately $3 \mathrm{~mm}$ thick zone containing several pinhead-sized whitish-yellow points. Histological examination showed these points to be Graafian follicles.

The number of cysts in the mesosalpinx and in the oviduct walls was high (Tables 1 and 2 ). Fifty-four cases $(5.4 \%$ ) of parovarian cysts without contact with oviduct or infundibulum were found, 3 of which were bilateral $(0.3 \%)$. In 3 cases the cystic structures were localized to the oviduct wall narrowing the lumen. In not less than 86 cases ( 14 bilateral) the cysts wero present in the infundibulum or attached to the fimbriated end 


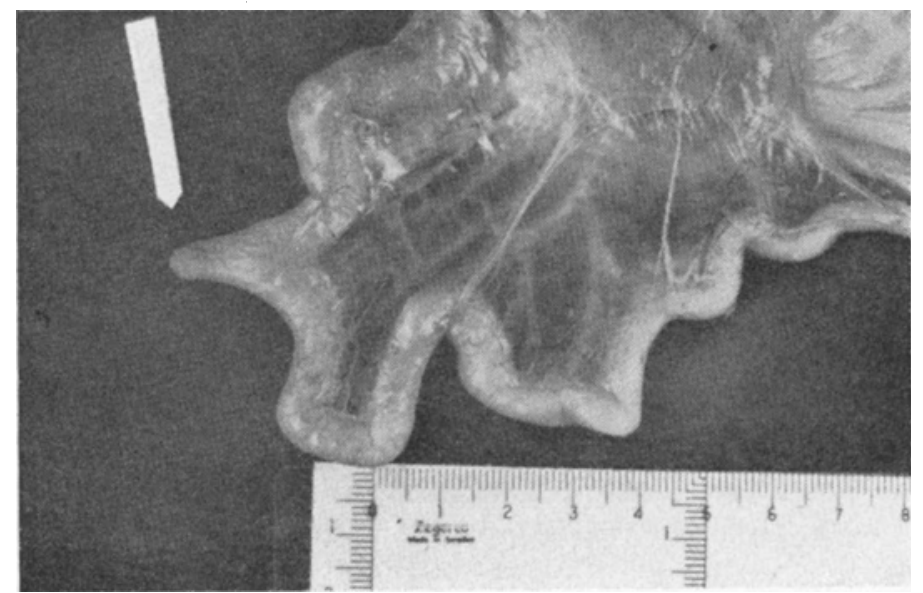

F i g u r e 3. Local diverticularization of oviduct wall, localized to proximal part of the oviduct.

of the tube. In 15 of 86 cases the size of the cysts was more than $10 \mathrm{~mm}$ in diameter. A case of bilateral cysts, present in infundibulum, is shown in Fig. 2.

No case of local aplasia of the oviduct was observed. Diverticularization of the oviduct wall was found in 14 cases $(1.4 \%)$, of which 3 with bilateral localization. In all cases there was communication between the relatively thin-walled diverticulum and the lumen of the oviduct. Usually the diverticula were present in the proximal part of the oviduct towards the infundibulum. Except for 2 cases, with 2 and 3 successive diverticula respectively in the same oviduct wall, there was only 1 diverticulum in each oviduct. A diverticulum in the proximal part of the oviduct wall is shown in Fig. 3.

Absence of 1 uterine horn (uterus unicornis) as well as the oviduct of the same side was observed in 4 cases $(0.4 \%)$, in 2 of which the right uterine horn and in 2, the left uterine horn was missing. A case of aplasia of the right uterine horn and oviduct of the same side is shown in Fig. 4. Uterus didelphys in combination with double vagina (Fig. 5) was found in 1 case.

Four cases $(0.4 \%)$ of segmental aplasia of the uterine horn were recorded. One of these was bilateral and 3 unilateral. Two of the unilateral cases were localized to the right horn. The aplasia included in all 4 cases a relatively short part of the uterine horn near the bifurcation. The uterine horn cranial to the aplasia was moderately distended by fluid. 


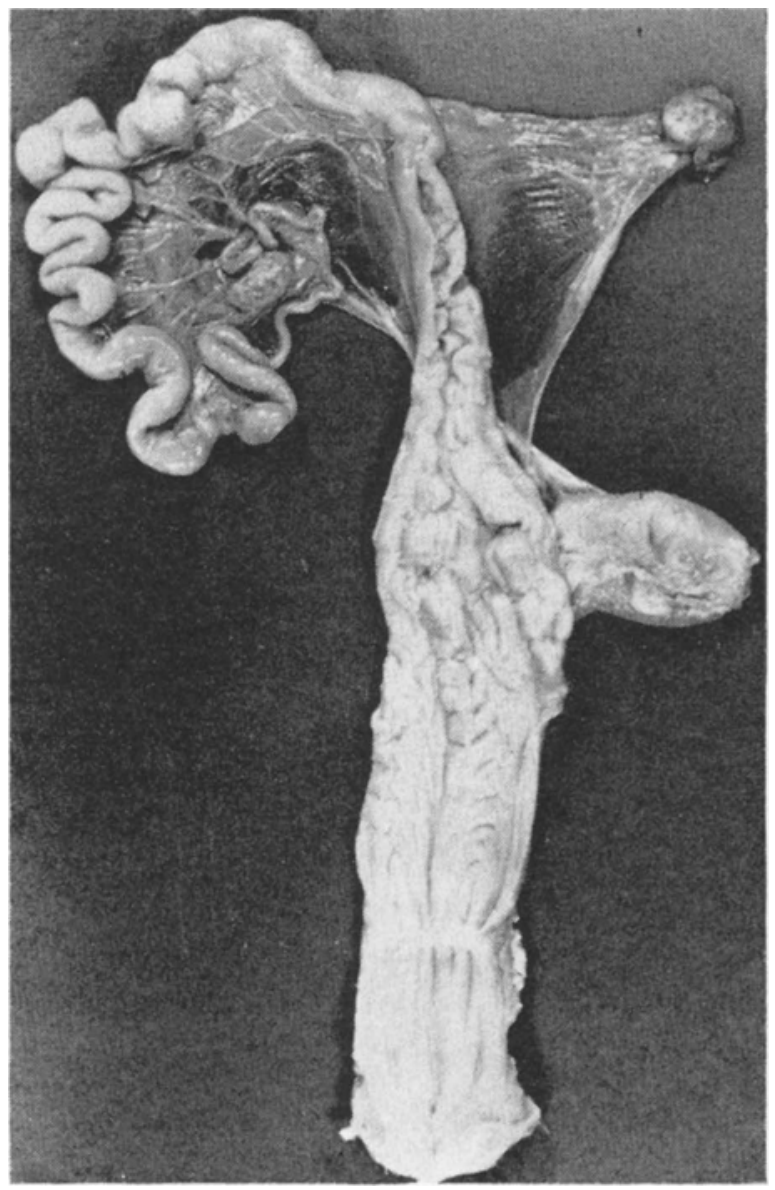

Figure 4. Uterus unicornis with absence of right horn and oviduct of the same side.

Another type of malformation of the uterus was a partial doubling of 1 uterine horn. This malformation was observed in 3 cases, 2 of which were localized to the left side. In all cases the double part of the horn began about $10 \mathrm{~cm}$ from the bifurcation and was $10-15 \mathrm{~cm}$ long. The double horns were both of the same size. The lumina were slightly smaller than the lumen of the normal single part of the horn. Histologically the external muscle layer was common to the double horns.

Incomplete fusion of the Müllerian ducts caused partial or total duplication of cervix and/or vagina (Table 1 ). Total duplication of both cervix and vagina was observed in 1 case, while 


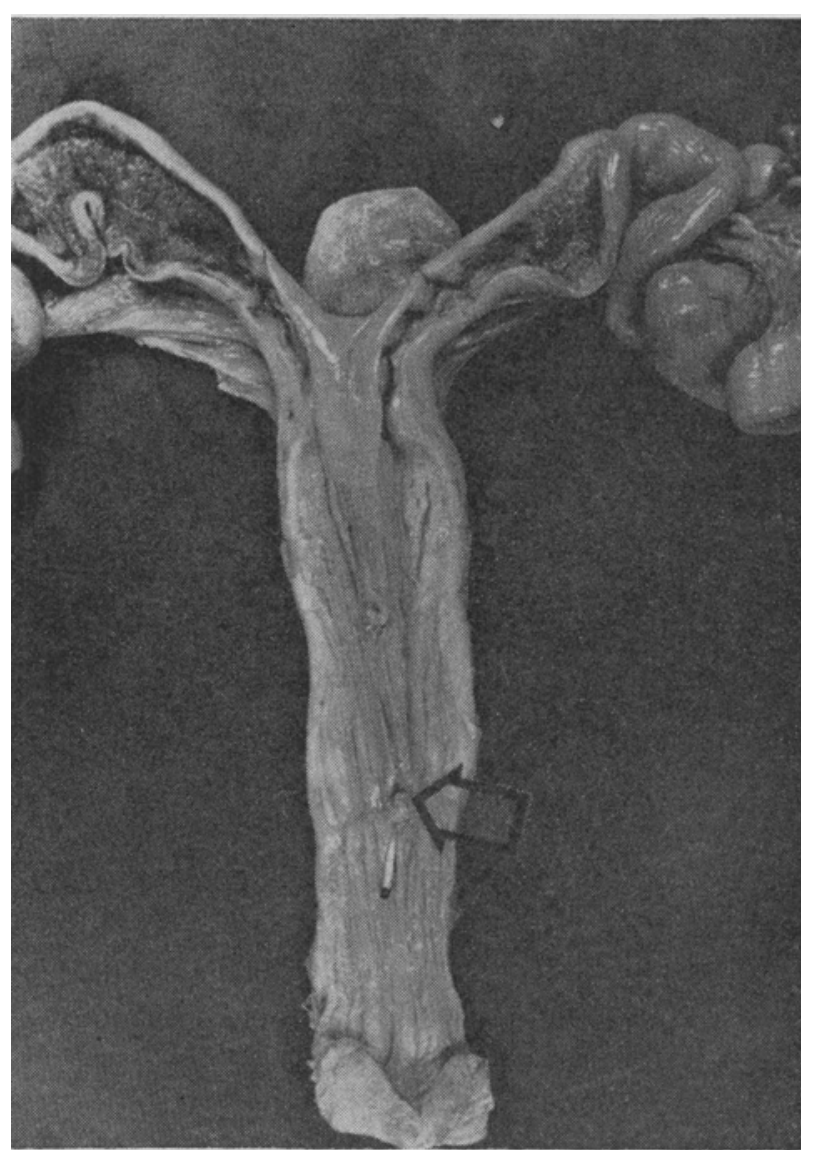

F i g u re 5. Uterus didelphys with double vagina. Note that the septum starts immediately in front of the urethral orifice (the arrow).

a total duplication of the vagina alone was recorded once. Partial duplication of the cervix alone occurred in 2 organs. A dorsoventral septum causing a partial duplication of the vagina occurred in 41 cases. The septa were more than $1 \mathrm{~cm}$ long and situated in the anterior vagina. Fig. 6 shows some cases of incomplete fusion of the Müllerian ducts with partial duplications localized to cervix-vagina.

Other defects of the sexual organs

Hymeneal rests. In several organs, both from prepuberal and from sexually mature gilts, hymeneal rests in the form of sagittal cords were found. The thickness of the cords varied between 


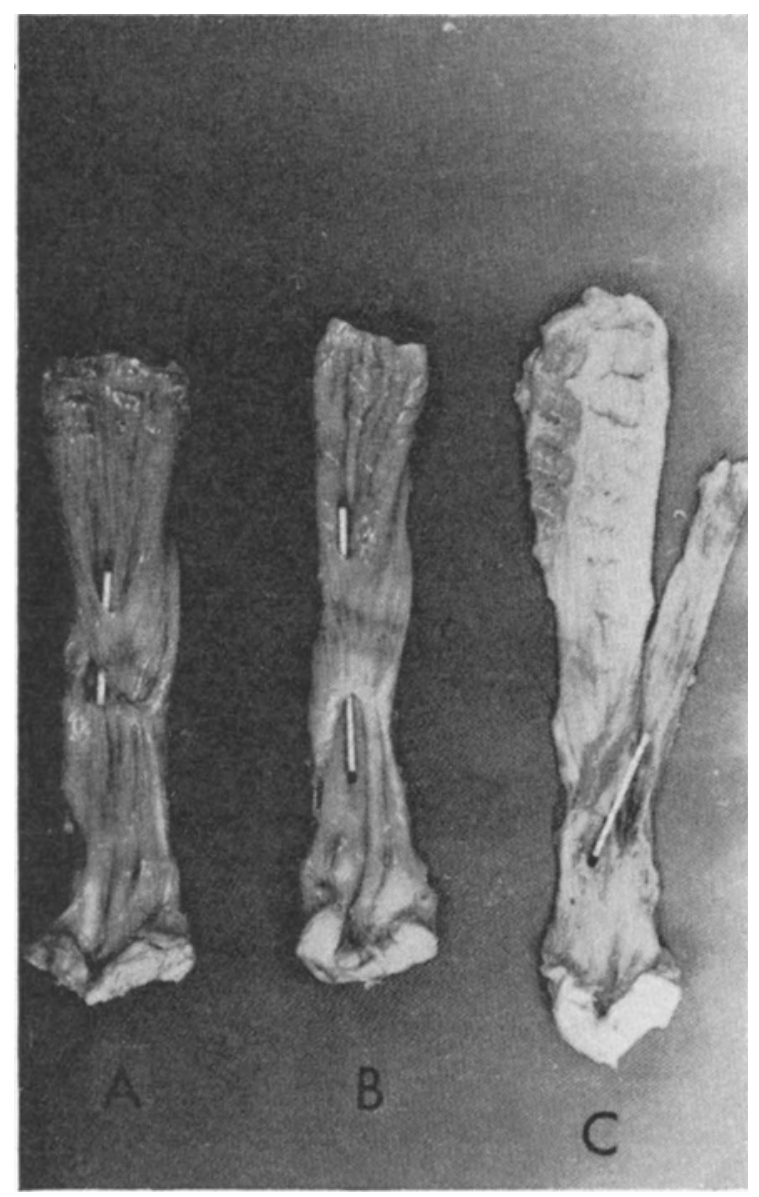

Figur e 6. Partial duplication of (A) vagina, (B) vagina and cervix, and (C) total septum between vagina and vestibulum vaginae.

1 and $6 \mathrm{~mm}$ (Table 3 ). Hymeneal constriction was observed in 41 cases $(4.1 \%), 6$ of which were from sexually mature gilts $(0.6 \%)$.

Hydrometra. Hydrometra (Fig. 7) was recorded in 33 cases $(3.3 \%)$. Thirty-one of these were from prepuberal gilts. In all cases the uterine horns were filled with a clear yellowish viscous fluid and the uterine wall was very thin, probably due to the fluid accumulation.

Cystic corpus luteum. In 34 out of a total of 202 examined organs (Table 4 ) the ovaries contained cystic corpora lutea, 


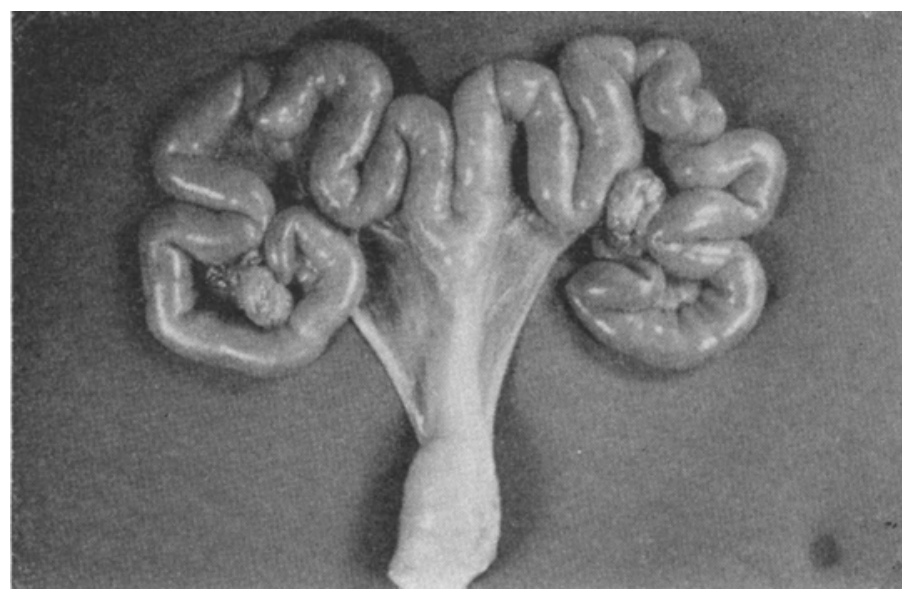

F i g u r e 7. Hydrometra in prepuberal gilt. Note the distension of the uterine horns.

which were characterized by a central cavity filled with fluid. The number of cystic corpora lutea varied, but as a rule there were 2-4 in each ovary. The largest diameter was $24 \mathrm{~mm}$. The wall of the cystic corpus luteum was generally $2-3 \mathrm{~mm}$ thick.

\section{Some reproductive physiological data}

Table 4 shows the distribution of organs from prepuberal and sexually mature gilts. The Table records the follicle diameter. Table 5 shows the weight of the ovaries. As will be seen, the left ovary was significantly heavier than the right. The number of corpora lutea was higher in the left ovary than in the right. The difference was highly significant (Table 6 ).

T a ble 3. Occurrence of hymeneal rests in prepuberal and sexually mature gilts $(1,000$ organs $)$.

\begin{tabular}{lrrrrr}
\hline & $\begin{array}{c}\text { Papilla } \\
\text { on site of } \\
\text { hymeneal rest } \\
\text { (pea-sized) }\end{array}$ & \multicolumn{2}{c}{$\begin{array}{c}\text { Connective tissue cord } \\
\text { thickness }(\mathrm{mm})\end{array}$} & $\begin{array}{c}\text { Semiconstricted } \\
\text { passage vagina - } \\
\text { vestibulum } \\
\text { vaginae }\end{array}$ \\
\cline { 3 - 5 } & $1-2.9$ & $3.0-5.9$ & $6.0-9.9$ & & 35 \\
Prepuberal & 10 & 228 & 48 & - & 6 \\
$\begin{array}{l}\text { Sexually mature } \\
\text { Total }\end{array}$ & 1 & 50 & 22 & - & 41 \\
\hline
\end{tabular}


T a b l e 4. Distribution of organs in main groups - prepuberal and sexually mature gilts - and grouping of prepuberal according to follicle diameter and of sexually mature according to occurrence of cystic C. L.

\begin{tabular}{|c|c|c|c|c|c|c|}
\hline \multicolumn{4}{|c|}{ Prepuberal } & \multicolumn{3}{|c|}{ Sexually mature } \\
\hline \multicolumn{3}{|c|}{ follicle diameter $\mathrm{mm}$} & \multirow{2}{*}{$\begin{array}{c}\text { total } \\
\text { no. }\end{array}$} & \multirow{2}{*}{$\begin{array}{l}\text { without cystic } \\
\text { corpora lutea }\end{array}$} & \multirow{2}{*}{$\begin{array}{l}\text { with cystic } \\
\text { corpora lutea }\end{array}$} & \multirow{2}{*}{$\begin{array}{l}\text { total } \\
\text { no. }\end{array}$} \\
\hline$\leq 5$ & $5<\mathrm{F} \leq$ & 10 & & & & \\
\hline 677 & 119 & 0 & 796 & $\begin{array}{l}168 \\
\text { (of which } 5 \\
\text { with } 1 \text { or more } \\
\text { follicles }> \\
10 \text { mm diam.) }\end{array}$ & $\begin{array}{l}\quad 34 \\
\text { (as a rule } \\
2-4 \text { in each } \\
\text { ovary with } \\
\text { up to } 24 \mathrm{~mm} \\
\text { diameter) }\end{array}$ & 202 \\
\hline
\end{tabular}

\section{DISCUSSION}

The material which was collected during the period MarchAugust consists of reproductive organs from female swine not yet pregnant. The live body weight varied between 85 and $110 \mathrm{~kg}$.

The left ovary contained more corpora lutea than the right (Table 4). The left ovary was also heavier than the right in both sexually mature and prepuberal gilts (Table 5). Accordingly there are indications that the left ovary is more active than the right. This is in agreement with previously published investigations by among others Corner (1921), Goethals (1951) and Roberts (1956). The predominance of the left ovary as regards the number of corpora lutea is, however, according to Goethals, not reflected in a higher number of foetuses in the left horn. On the contrary the foetuses seem to be equally distributed in the 2 horns, probably due to transuterine migration during early pregnancy.

The total number of defects of the reproductive organs (Table 1) was $22.1 \%$. Parovarian cysts were responsible for $14 \%$ and partial duplication of the vagina for $4.1 \%$. The remaining $4 \%$ were general developmental abnormalities $(0.3 \%)$ and local developmental defects of the Müllerian ducts $(3.7 \%)$. The frequency of abnormalities of the tubular system is in close agreement with that reported for cattle breeds in Sweden (Lagerlöf et al. 1958; Settergren \& Galloway 1965). A comparison between the present and previously published results of malformations of the genital tract (Wiggins et al. 1959; Goethals; Teige 1957; Nalbandov 1964) shows that the frequency is about the 
T a b l e 5. Mean weights (g) of right and left ovaries of prepuberal and sexually mature gilts.

\begin{tabular}{lcccc}
\hline & & Right ovary & Left ovary \\
\hline Prepuberal & $\mathrm{n}$ & 796 & & 796 \\
& $\overline{\mathrm{x}}$ & 2.48 & & 2.74 \\
& $\mathrm{~S}$ & 0.74 & $6.95^{\star \star \star}$ & \\
Sexually mature & $\mathrm{t}$ & & & \\
& $\mathrm{n}$ & 202 & & 202 \\
& $\mathrm{x}$ & 4.91 & & 5.68 \\
Total & $\mathrm{s}$ & 2.09 & & 2.67 \\
& & & & \\
& $\mathrm{n}$ & 998 & & 3.398 \\
& $\overline{\mathrm{x}}$ & 2.97 & & 1.81 \\
& $\mathrm{~S}$ & 1.54 & & \\
\hline
\end{tabular}

same. However, the localization of defects, particularly as regards the tubular system, differs in some respects between the present material and that mentioned above. For example Wiggins et al. and Nalbandov reported that defects localized to the oviduct were the most common cause of sterility in gilts. The abnormalities of the oviduct observed by these authors were, however, mostly hydrosalpinx and pyosalpinx. In the present material such diseases of the oviduct were not observed. Apart from the diverticularization there was no local developmental abnormality of the oviduct.

Abnormalities with potential influence on fertility (Table 1) were recorded in $4.5 \%$ of all examined organs, of which $0.8 \%$ were presumed to cause permanent sterility and $3.7 \%$ impaired fertility in the form of reduced size of litters.

The frequency of hermaphroditism was $0.3 \%$, which is in accordance with the figures given by Johansson \& Rendel (1963) for Swedish swine breeds. One of the cases in the present investi-

T a ble 6. Comparison of number of corpora lutea (C.L.) in right and left ovaries. Total number of animals 202.

\begin{tabular}{lcccc}
\hline & Right ovary & Left ovary \\
\hline Number of corpora lutea & mean & 5.4 & & 6.3 \\
& $\mathrm{~s}$ & 2.0 & & 2.1 \\
& $\mathrm{t}$ & & $4.50^{\star \star \star}$ & \\
\hline
\end{tabular}


gation showed such changes of the external genitalia that a clinical diagnosis would have been possible.

Large numbers of parovarian cysts were recorded. Wiggins et al. are of the opinion that parovarian cysts do not impair fertility. In our opinion, however, it is very probable that cysts localized to the infundibulum or its fimbria impair the function of the infundibulum during ovulation. We assume that cysts with a diameter of more than $10 \mathrm{~mm}$ may cause reduced fertility (Table 1). Cysts localized to the wall of the oviduct may be a fertility-reducing factor, as also may the oviduct diverticula. These diverticula situated in the proximal third of the oviduct and in communication with its lumen have apparently not been described previously. Segmental aplasia of one uterine horn causes complete sterility according to Nalbandov. It seems that the distended occluded horn influences the endometrium in the opposite normal uterine horn so as to make egg implantation impossible. The mechanism for this effect is not well established. Experimental investigations in swine in which part of one uterine horn has been surgically removed have, however, confirmed that this effect exists (cf. Ginther 1967). 'The hypothesis is that the effect is exerted via the ovaries. Consequently there exists a local utero-ovarian relationship. The same phenomenon has on the other hand not been observed in other multiparous animals (cf. Ginther).

The frequency of uterus unicornis was $0.4 \%$. The occurrence of this abnormality has been reported by, among others, Wiggins et al., who found a frequency of $0.3 \%$ in a slaughterhouse material, and by Teige, who reported a frequency of $0.15 \%$ in gilts. According to Nalbandov the defect will not influence pregnancy in the normal uterine horn, but the size of litter is reduced. Partial doubling of 1 of the uterine horns, in the present material observed in 3 cases, has previously been described by several investigators, inter alia Wiggins et al., Teige, and Dhindsa \& Dziuk (1967). Dhindsa \& Dziuk found 5 cases among 500 examined organs from gilts. Normal pregnancy was recorded in 3 of these cases. The defect may have an obstetrical interest by causing complications at parturition (Teige).

The abnormalities localized to the cervix and vagina consisted mainly of vertical septa of varying length, most of which were situated in the anterior vagina. Most probably these defects have no deleterious influence on fertility, but in extreme cases 
with extensive duplication they may cause mating difficulties or make the insemination difficult. Complete persistence of hymen was not observed in the present material. On the other hand hymeneal rests of varying thickness occurred (Table 3) as well as hymeneal constriction. Both conditions may cause parturition difficulties (Teige).

Hydrometra, which was fairly common in the present material, has previously been reported by others (Goethals, and Teige). Goethals considers it to be a prepuberal condition, while Teige reports that hydrometra also occurs in sexually mature gilts. In the present material only 2 cases were from sexually mature gilts. It is, however, impossible at present to decide whether the condition has any influence on fertility. In cows hydrometra occurs in connection with cystic ovaries (Roberts). In sheep Gustafsson \& Holmberg (1966) described 2 cases of hydrometra. The ovaries were normal and there was no anatomical defect in the tubular system. A functional stenosis in the cervix was considered to be a possible cause of the condition.

The significance of the high frequency of cystic corpora lutea is difficult to evaluate. In cattle Hammond (1927) considers them to have no importance for fertility, while Asdell et al. (1949) hold an opposite opinion. Later authors, such as McEntee \& Jubb (1957) and McEntee (1958), have reported that cystic corpora lutea cause irregularity of the sexual cycle of the cow. Hansel (1964) found a lower progesterone concentration in cystic than in normal corpora lutea from heifers. The importance of cystic corpora lutea in swine is not known, but the present authors have observed the condition in organs both from pregnant sows and from gilts (Einarsson \& Gustafsson 1969).

\section{REFERENCES}

Asdell, S. A., J. de Alba \& S. J. Roberts: Studies on the oestrous cycle of dairy cattles: cycle length, size of corpus luteum and endometrial changes. Cornell Vet. 1949, 39, 389-402.

Bornstein, S.: Hermafroditism - en översikt. (Hermaphroditism a review). Svensk Vet.-Tidn. 1965, 17, 12-18, 38-52.

Corner, G. W.: Cyclic changes in the ovaries and uterus of the sow and their relation of the mechanism of implantation. Contr. Embryol. Carneg. Instn. 1921, 13, 119-146.

Dhindsa, D. S. \& P. J. Dziuk: Partial doubling of the uterine horns in the gilt. Vet. Med. small. Anim. Clin. 1967, 62, 900-902.

Einarsson, S. \& B. Gustafsson: Unpublished observations, 1969.

Eriksson, K.: Hereditary forms of sterility in cattle. Thesis. Stockholm 1943. 
Ginther, O. J.: Local utero-ovarian relationships. J. Animal Sci. 1967, $26,578-585$.

Goethals, P.: Studie van het Geschlachtsapparaat van Zengen met betrekking tot Onvruchtbaarheid en verminderde Vruchtbaarheid. (Studies on the sexual organs of sows with reference to sterility and reduced fertility). Vlaams diergeneesk. T. 1951, 20, 155165.

Gustafsson, B. \& O. Holmberg: Post-Mortemundersökning av könsorgan från tackor med speciell hänsyn till förekomst av missbildningar. (Post-mortem examination of the genital tract in ewes with special reference to the occurrence of developmental abnormalities). Svensk Vet.-Tidn. 1966, 18, 432-436.

Hammond, J.: The physiology of reproduction in the cow. University Press, Cambridge 1927.

Hansel, W.: Some observations on bovine cystic corpora lutea. Proc. Vth Int. Congr. Anim. Reprod., Trento 1964, vol. 5, 378-384.

Holst, S.: Sterility in boars. Nord. Vet.-Med. 1949, 1, 87-120.

Johansson, I. \& J. Rendel: Ärftlighet och husdjursförädling. (Animal genetics). LT:s förlag, Stockholm 1963, 368.

Lagerlöf, N. \& H. Boyd: Ovarian hypoplasia and other abnormal conditions in the sexual organs of cattle of the Swedish highland breed: results of post-mortem examination over 6000 cows. Cornell Vet. 1953, 43, 64--79.

Lagerlöf, N., M. Abdel-Raouf \& I. Settergren: Undersökningar av könsorganen från hondjur av Svensk Låglands- och Fjällras på förekomsten av missbildningar. (Post-mortem examination of the sexual organs of cows of the Swedish-Highland breed and the Swedish Friesian breed with special reference to ovarian hypoplasia and malformation of the Müllerian ducts). Proc. 8. Nord. Vet. Congr., Helsinki 1958, 584-589.

McEntee, K.: Cystic corpora lutea in cattle. Int. J. Fertil. 1958, 3, 120195.

McEntee, K. \& K. V. Jubb: Functional cytology of the bovine adenohypophysis in relation to cystic ovaries. Int. J. Fertil. 1957, 2, $279-286$.

Nalbandov, A .V.: Anatomic and endocrine causes of sterility in female swine. Fertil. and Steril. 1964, 3, 100-120.

Perry, S. J. \& R. W. Pommery: Abnormalities of the reproductive tract of the sow. J. agric. Sci. 1956, 47, 238-248.

Roberts, S. J.: Veterinary Obstetrics and Genital Diseases. Ithaca, New York 1956. (Distributed by Edwards Brothers, Inc., Ann. Arbor., Michigan).

Settergren, I. \& D. Galloway: Studies on genital malformations in female cattle using slaughterhouse material. Nord. Vet.-Med. $1965,17,9-16$.

Teige, J.: Congenital malformations of the Müllerian ducts and sinus urogenitalis in pigs. Nord. Vet.-Med. 1957, 9, 609-629.

Wiggins, E. L., L. E. Casida \& R. H. Grummer: The incidence of female genital abnormalities of swine. J. Animal Sci. 1950, 9, 269-276. 


\section{SUMMARY}

One thousand reproductive organs from gilts were collected during the period March-August at a slaughterhouse in central Sweden. The organs were inspected in respect of congenital defects and certain reproductive physiological data. The results are recorded in Tables $1-6$. Figs. $1-7$ show some types of malformations.

The total frequency of malformations was $22.1 \%$, of which $14 \%$ cysts in mesosalpinx and $4.1 \%$ partial duplication of the vagina. The remainder consisted of general developmental defects and of local defects in the tubular genital tract. Malformations with presumed effect on fertility were found in $4.5 \%$ of all organs examined, of which $0.8 \%$ presumably caused permanent sterility and $3.7 \%$ lowered fertility (small litters).

Hydrometra was found in 33 cases, 2 of which in sexually mature gilts.

The left ovary contained more corpora lutea than the right, and the mean weight of the left ovary was greater than that of the right, both in sexually mature and prepuberal gilts. Of 202 sexually mature gilts examined $16.9 \%$ had cystic corpora lutea in their ovaries as a rule $2-4$ in each ovary.

\section{SAMMANFATTNING}

Misbildningar $i$ de honliga könsorganen hos svin.

En post mortem undersökning av 1000 könsorgan från gyltor.

Ettusen könsorgan från gyltor insamlades under tiden marsaugusti vid ett slakteri i mellansverige. Könsorganen undersöktes med avseende på medfödda defekter samt vissa sexualfysiologiska data. Resultaten finns redovisade i Tabellerna $1-6$. Figurerna $1-7$ visar några typer av missbildningar.

Totalt förekom en missbildningsfrekvens på 22,1\%, där cystabildningar i mesosalpinx svarade för $14 \%$, och partiella tudelningar av vagina för 4,1\%. Övriga utgjordes dels av allmänna utvecklingsdefekter dels av lokala defekter lokaliserade till de tubulära delarna av könsorganen. Missbildningar ıned förmodad inverkan på fertiliteten förekom i 4,5 \% av samtliga undersökta organ, varav $0,8 \%$ förmodades ge permanent sterilitet och $3,7 \%$ sänkt fruktsamhet (små kullar).

Hydrometra påträffades i 33 fall varav 2 hos könsmogna gyltor och övriga hos icke könsmogna gyltor.

Vänster äggstock innehöll fler gula kroppar än höger äggstock och medelvikten för vänster äggstock var högre än för höger äggstock både hos könsmogna och icke könsmogna gyltor. Av 202 undersökta könsmogna gyltor hade $16,9 \%$ cystösa gula kroppar i sina äggstockar, som regel 2-4 i vardera äggstocken. 